University of South Carolina

Scholar Commons

\title{
Electrochemical Removal of Carbon Monoxide in Reformate Hydrogen for Fueling Proton Exchange Membrane Fuel Cells
}

\author{
Sivagaminathan Balasubramanian \\ University of South Carolina - Columbia \\ Charles E. Holland \\ University of South Carolina - Columbia, hollance@cec.sc.edu \\ John W. Weidner \\ University of South Carolina - Columbia, weidner@engr.sc.edu
}

Follow this and additional works at: https://scholarcommons.sc.edu/eche_facpub

Part of the Chemical Engineering Commons

\section{Publication Info}

Electrochemical and Solid-State Letters, 2009, pages B5-B7.

(c) The Electrochemical Society, Inc. 2009. All rights reserved. Except as provided under U.S. copyright law, this work may not be reproduced, resold, distributed, or modified without the express permission of The Electrochemical Society (ECS). The archival version of this work was published in Electrochemical and Solid-State Letters.

http://www.electrochem.org/

DOI: $10.1149 / 1.3267850$

Publisher's Version: http://dx.doi.org/10.1149/1.3267850

This Article is brought to you by the Chemical Engineering, Department of at Scholar Commons. It has been accepted for inclusion in Faculty Publications by an authorized administrator of Scholar Commons. For more information, please contact digres@mailbox.sc.edu. 


\title{
Electrochemical Removal of Carbon Monoxide in Reformate Hydrogen for Fueling Proton Exchange Membrane Fuel Cells
}

\author{
Sivagaminathan Balasubramanian, Charles E. Holland,* and John W. Weidner, \\ Center for Electrochemical Engineering and Department of Chemical Engineering, \\ University of South Carolina, Columbia, South Carolina 29208, USA
}

\begin{abstract}
A twin-cell electrochemical filter is demonstrated to reduce the $\mathrm{CO}$ concentration in reformate hydrogen. In this design, the potential and gas flow are switched between the two filter cells so that alternative CO adsorption and oxidation occur in each cell while providing a continuous flow of $\mathrm{H}_{2}$ to a fuel cell. The effects of filter switching time and applied potential on the CO concentration of gas exiting the filter are presented here for a CO concentration of $1000 \mathrm{ppm}$ in nitrogen flowing at $100 \mathrm{~cm}^{3} / \mathrm{min}$. The parasitic loss of hydrogen from a corresponding reformate stream was estimated to be $1.5 \%$. (C) 2009 The Electrochemical Society. [DOI: 10.1149/1.3267850] All rights reserved.
\end{abstract}

Manuscript submitted August 25, 2009; revised manuscript received November 3, 2009. Published December 8, 2009. This was Paper 1116 presented at the Vienna, Austria, Meeting of the Society, October 4-9, 2009.

Carbon monoxide $(\mathrm{CO})$ in hydrogen reformed from carbonbased fuels is known to degrade the performance of a proton exchange membrane fuel cell (PEMFC) by poisoning the anode active sites, as shown in Reaction $1^{1-4}$

$$
\mathrm{Pt}+\mathrm{CO} \rightarrow \mathrm{Pt}-\mathrm{CO}
$$

To mitigate the detrimental effects of $\mathrm{CO}$ on the performance of a PEMFC, researchers have explored ways to modify fuel cell operation by using elevated temperatures (e.g., $120{ }^{\circ} \mathrm{C}$ ), ${ }^{5-7}$ air bleeding, ${ }^{8}$ or in situ voltage pulsing. ${ }^{9,3}$ Even with these techniques, fuel cells may not tolerate the concentration level of $\mathrm{CO}$ coming out of a reformer, which is typically $0.1-1 \%(1000-10,000 \mathrm{ppm})$. To reduce the $\mathrm{CO}$ concentration in reformate $\mathrm{H}_{2}$ to parts per million levels, methods such as pressure swing adsorption, ${ }^{10}$ preferential oxidation, ${ }^{11-14}$ or catalytic methanation ${ }^{15-18}$ can be used. However, volume, weight, power, and fuel-efficiency penalties may be substantial when using these methods, particularly for small-scale fuel cell systems. Balasubramanian et al. ${ }^{19}$ proposed a single-cell electrochemical CO filter external to the fuel cell. This filter lowers the $\mathrm{CO}$ concentration by periodically oxidizing the adsorbed $\mathrm{CO}$ via the following reaction ${ }^{2}$

$$
\mathrm{Pt}-\mathrm{CO}+\mathrm{H}_{2} \mathrm{O} \rightarrow \mathrm{Pt}
$$

However, low exit $\mathrm{CO}$ concentrations and a high selectivity of $\mathrm{CO}$ to $\mathrm{H}_{2}$ oxidation could not be simultaneously achieved due to the reformate continuously flowing through the filter cell during oxidation.

To achieve both low exit $\mathrm{CO}$ concentration and low $\mathrm{H}_{2}$ consumption, we demonstrate here a twin-cell filter design in which the flow of the reformate and the potential are switched between two proton exchange membrane filter cells. In the adsorption mode, COcontaminated $\mathrm{H}_{2}$ is passed through the anode of one filter cell at open circuit. Simultaneously, a pulse potential is applied to the other filter cell, oxidizing the $\mathrm{CO}$ adsorbed a priori. Although hydrogen is also oxidized during pulsing, only the hydrogen confined to the anode compartment is lost. Here, we show the effect of switching time and applied potential on the concentration of $\mathrm{CO}$ in a gas exiting the filter cells. The stream tested here is $1000 \mathrm{ppm} \mathrm{CO}$ in nitrogen to isolate and to analyze the adsorption and oxidation rates of $\mathrm{CO}$.

\footnotetext{
* Electrochemical Society Active Member.

z E-mail: weidner@cec.sc.edu
}

\section{Experimental}

Filter cell construction.- The electrodes (E-TEK) used in the filter cells had an active area of $10 \mathrm{~cm}^{2}$ and a catalyst loading of $0.5 \mathrm{mg} / \mathrm{cm}^{2}$ of platinum. The channels in the anode flow fields had a volume of $0.458 \mathrm{~cm}^{3}$. The membrane electrode assemblies for the filter cells were prepared as described previously. ${ }^{19}$ The gas flow, temperature, and pressure were controlled using a test station and hardware from Fuel Cell Technologies, Inc. All experiments were carried out at $25^{\circ} \mathrm{C}$ and $1 \mathrm{~atm}$. A CO concentration of $1000 \mathrm{ppm}$ in $\mathrm{N}_{2}$ with no humidification flowing at $100 \mathrm{~cm}^{3} /$ min was used as the $\mathrm{CO}$ source for the anode. The cathode, with fully humidified $4 \%$ $\mathrm{H}_{2} / \mathrm{N}_{2}$ gas flowing at $40 \mathrm{~cm}^{3} / \mathrm{min}$, acted as the counter and reference electrodes. All the gases used were procured from Praxair, Inc. The CO concentration in the gas stream was quantified using an online gas chromatograph (Buck Scientific, model 910) equipped with a calibrated flame ionization detector. The electrochemical experiments were carried out with a potentiostat (Bio-Logic, model VMP3).

$\mathrm{CO}-\mathrm{SCV}$ - - CO stripping cyclic voltammetry (CO-SCV) was used to quantify and remove the $\mathrm{CO}$ adsorbed on the anode of the filter cell. This was done by scanning the filter anode between 0.05 and $1.0 \mathrm{~V}$ for two cycles at a rate of $50 \mathrm{mV} / \mathrm{s}$. The adsorbed $\mathrm{CO}$ was quantified by integrating the charge under the $\mathrm{CO}$ oxidation peak corrected for the background current. ${ }^{20-22}$

CO breakthrough curve.- The $\mathrm{CO}$ breakthrough curves were generated by exposing a CO-free filter cell at open circuit to $\mathrm{CO} / \mathrm{N}_{2}$ for a period of time (i.e., adsorption time) and by analyzing the gas exiting the filter anode for $\mathrm{CO}$ concentration using a gas chromatograph flame ionization detector (GC-FID). Then, the CO adsorbed on the filter anode was quantified using CO-SCV. After removing the adsorbed $\mathrm{CO}$ by CO-SCV, the experiment was repeated for different adsorption times.

CO oxidation.- To understand the effect of the applied pulse potential during the oxidation mode, the filter anode was exposed to $\mathrm{CO} / \mathrm{N}_{2}$ for a period of time. Then, a pulse potential was applied for the same period of time, and the current response was monitored during the period. After the pulse, the $\mathrm{CO}$ adsorbed on the filter anode was quantified using CO-SCV. This experiment was repeated for pulses of different potentials.

Filter operation.- To demonstrate the filter operation, a $\mathrm{CO} / \mathrm{N}_{2}$ stream was fed to the anodes of the two filter cells, and the anode exits were connected to the GC-FID. A relay mechanism was used to switch gas flow between the filters and to synchronize the adsorption and oxidation modes of the filters according to a preset switching 


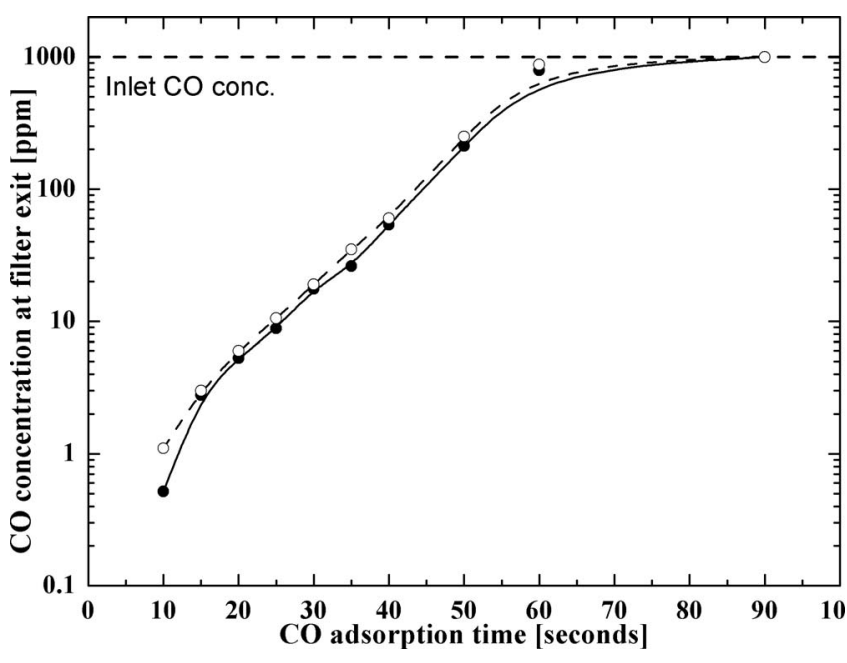

Figure 1. CO concentration at the anode exit of the filter cells measured as a function of adsorption time of $1000 \mathrm{ppm}$ of $\mathrm{CO} / \mathrm{N}_{2}$ flowing at $100 \mathrm{~cm}^{3} / \mathrm{min}, 25^{\circ} \mathrm{C}$, and 1 atm (closed symbols, filter 1 ; open symbols, filter 2).

time. The synchronized twin-cell filter experiments were carried out for different switching times and for a fixed oxidation potential.

\section{Results and Discussion}

CO breakthrough curve.- The $\mathrm{CO}$ breakthrough curves for each of the two filter cells are shown in Fig. 1. The concentration of $\mathrm{CO}$ in the exit stream increased from approximately $1 \mathrm{ppm}$ after 10 $\mathrm{s}$ to $10 \mathrm{ppm}$ after $20 \mathrm{~s}$ and, finally, to $1000 \mathrm{ppm}$ (i.e., inlet concentration) after $90 \mathrm{~s}$. The difference between the inlet and exit $\mathrm{CO}$ concentrations, as measured by the GC-FID, was equal to the amount of adsorbed $\mathrm{CO}$ estimated from $\mathrm{CO}-\mathrm{SCV}$, confirming the accuracy of the data. The breakthrough curves for $\mathrm{CO}$ in $\mathrm{N}_{2}$ were similar to those for $\mathrm{CO}$ in $\mathrm{H}_{2}$, confirming that $\mathrm{CO}$ adsorption is not greatly affected by the presence of $\mathrm{H}_{2}$. This is consistent with Vogel et al., ${ }^{23}$ who showed that $\mathrm{CO}$ adsorption dominates hydrogen adsorption at low temperatures. The net $\mathrm{CO}$ adsorption capacity of each filter anode, as determined from CO-SCV from a CO saturated filter anode, was $4.65 \mu \mathrm{mol}\left(0.465 \mu \mathrm{mol} / \mathrm{cm}^{2}\right)$. An ideal filter, with no resistance to diffusion and adsorption, would adsorb all $\mathrm{CO}$ molecules entering the filter before any $\mathrm{CO}$ molecule exits the filter. Hence, a step change in the exit $\mathrm{CO}$ concentration from zero to the inlet concentration would be observed. For these filter cells under these flow conditions, the step change would have occurred after 60 s. The observed exponential increase in the exit $\mathrm{CO}$ concentration before reaching a steady-state value indicates a finite $\mathrm{CO}$ diffusion and adsorption rate. For an adsorption time of $20 \mathrm{~s}$, the exit $\mathrm{CO}$ concentration was less than $10 \mathrm{ppm}$, and the corresponding coverage of the active sites was $0.155 \mu \mathrm{mol} / \mathrm{cm}^{2}$, which was $33 \%$ of the CO adsorption capacity. Therefore, $20 \mathrm{~s}$ was chosen as the base case switching condition for demonstrating filter operation.

$\mathrm{CO}$ oxidation.- To determine the suitable pulse potential for a switching time of $20 \mathrm{~s}$, the oxidation experiments were carried out for $20 \mathrm{~s}$ pulses of potentials $0.65,0.7$, and $0.75 \mathrm{~V}$ followed by CO-SCV. Figure 2 shows the current response of the filter anode, which was pre-exposed to $\mathrm{CO} / \mathrm{N}_{2}$ for $20 \mathrm{~s}$. The current response shows two major features: $(i)$ The initial sharp decline observed in the first $0.5 \mathrm{~s}$ is mainly attributed to the charging of the electrode double-layer capacitance, and (ii) the current decay afterward is attributed to the $\mathrm{CO}$ oxidation current. The amount of $\mathrm{CO}$ not oxidized by the pulse was quantified by integrating the $\mathrm{CO}$ oxidation peak from the CO-SCV results. The inset in Fig. 2 compares the CO left on the anode after the pulse to the initial $\mathrm{CO}$ adsorbed on the anode after $20 \mathrm{~s}$ of adsorption. Pulses of 0.65 and $0.7 \mathrm{~V}$ oxidized 85

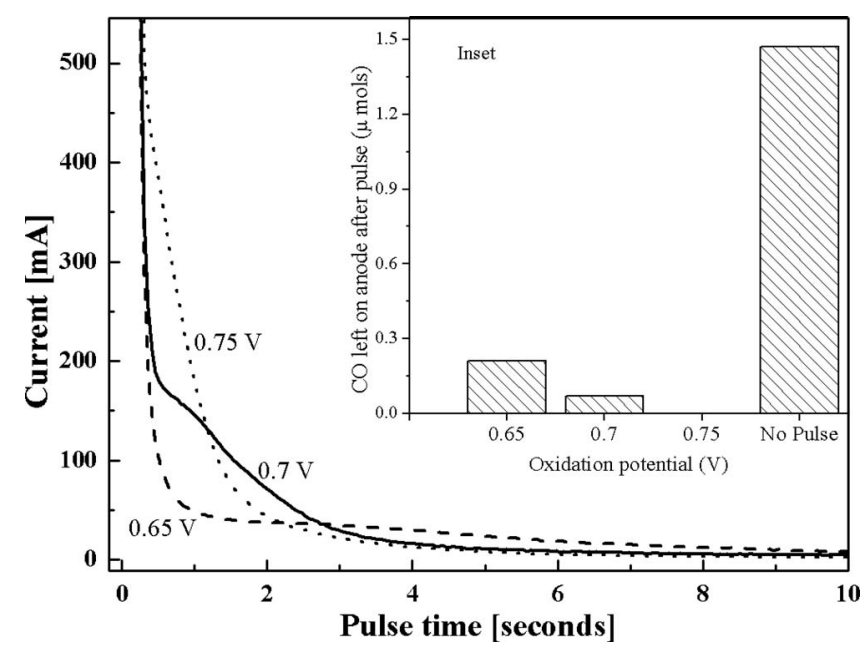

Figure 2. Current response of the filter anode exposed to $1000 \mathrm{ppm}$ of $\mathrm{CO} / \mathrm{N}_{2}$ for $20 \mathrm{~s}$ at $100 \mathrm{~cm}^{3} / \mathrm{min}$ flow rate, $25^{\circ} \mathrm{C}$, and $1 \mathrm{~atm}$ for different oxidation potentials of $0.65,0.7$, and $0.75 \mathrm{~V}$ vs $4 \% \mathrm{H}_{2} / \mathrm{N}_{2}$ at the cathode. The inset compares the $\mathrm{CO}$ left adsorbed on the filter anode immediately after the pulse and when no pulse was applied.

and $95 \%$ of the $\mathrm{CO}$ adsorbed in $20 \mathrm{~s}$, respectively, whereas a $0.75 \mathrm{~V}$ pulse oxidized the entire $\mathrm{CO}$ adsorbed. Because a complete removal of adsorbed $\mathrm{CO}$ occurred at $0.75 \mathrm{~V}$, this was chosen as the oxidation potential for filter demonstration.

Filter operation.- To evaluate a continuous filtering of $\mathrm{CO}$ in a stream, two filter cells were connected. The filter was operated at a pulse potential of $0.75 \mathrm{~V}$ and at different switching times of 10,20 , and $30 \mathrm{~s}$ to see if the concentration of $\mathrm{CO}$ in a continuous stream of $\mathrm{CO} / \mathrm{N}_{2}$ can be controlled using the twin-cell electrochemical filter design. The gas was sampled and analyzed with GC-FID at the end of the adsorption time of a cycle, in which the $\mathrm{CO}$ concentration was maxima, and the results were plotted (see Fig. 3). For 20 and $30 \mathrm{~s}$ switching times, the exit $\mathrm{CO}$ concentration was around 10 and 40 ppm, respectively, which was consistent with the adsorption breakthrough curve (see Fig. 1). The steady concentration indicates the recyclability of active sites during the oxidation mode. However, for the $10 \mathrm{~s}$ switching time, the CO concentration increased from less

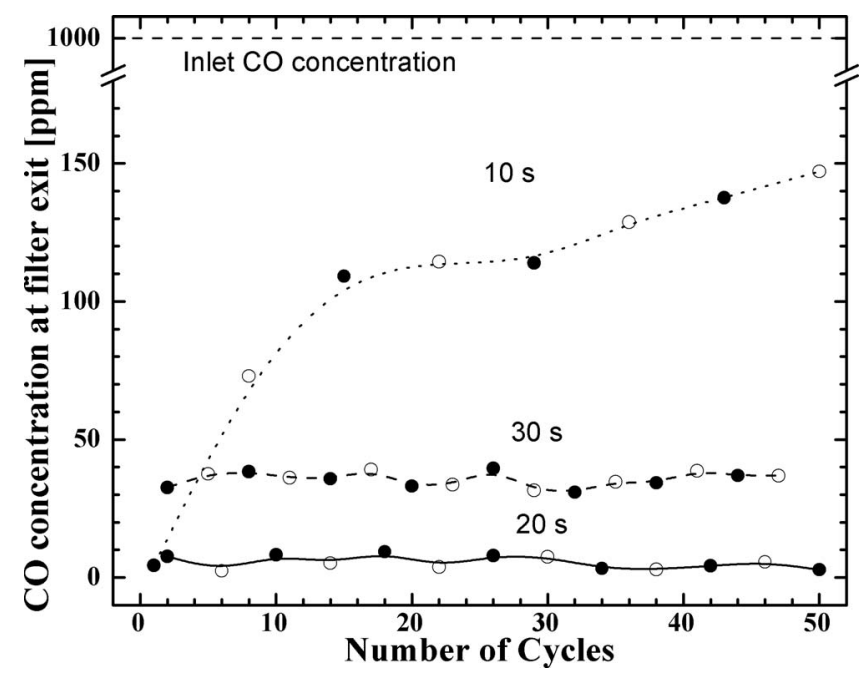

Figure 3. $\mathrm{CO}$ concentration of the gas exiting the filter operated with a pulse potential of $0.75 \mathrm{~V}$ vs $4 \% \mathrm{H}_{2} / \mathrm{N}_{2}$ at the cathode. The inlet $\mathrm{CO}$ concentration was $1000 \mathrm{ppm}$ in $\mathrm{N}_{2}$ flowing at $100 \mathrm{~cm}^{3} / \mathrm{min}$ for different switching times at $25^{\circ} \mathrm{C}$ and 1 atm (closed symbols, filter 1 ; open symbols, filter 2 ). 
than $10 \mathrm{ppm}$ after the first cycle to $150 \mathrm{ppm}$ with continuous operation. Despite a shorter adsorption time, the increase in the exit CO concentration was attributed to the incomplete recovery of the active sites through the oxidation of the adsorbed CO. The incomplete recovery of the active sites led to a decrease in the $\mathrm{CO}$ adsorption capacity of the filter during the adsorption mode with time. Despite the oxidation of most of the $\mathrm{CO}$ in the first $10 \mathrm{~s}$ (see Fig. 2), the $\mathrm{CO}$ oxidized and the active sites recovered in the last $10 \mathrm{~s}$ are important for a steady filter performance. The filter performance for 20 and 30 $\mathrm{s}$ switching times shows the importance of adsorption time in achieving the desired $\mathrm{CO}$ concentration, whereas the $10 \mathrm{~s}$ switching time shows the limitation of a low switching time in recovering the electrode active sites during oxidation.

The difference between filtering $\mathrm{CO}$ from $\mathrm{H}_{2}$ and filtering $\mathrm{CO}$ from $\mathrm{N}_{2}$ is the additional oxidation due to hydrogen. However, only $\mathrm{H}_{2}$ trapped in the cell during the oxidation step is consumed. Therefore, the parasitic loss of $\mathrm{H}_{2}$ from a reformate stream can be calculated from the operating parameters of the filter and fuel cells. Consider, for example, a twin-cell filter for removing $\mathrm{CO}$ from a reformate stream $\left(50 \% \mathrm{H}_{2}, 1000 \mathrm{ppm} \mathrm{CO}\right.$, and balance inert gases) feeding a fuel cell. Assume that each filter cell has the same active area as the fuel cell, so the ratio of the twin-cell filter area to the fuel cell stack area is $2: 1$. Furthermore, assume that the fuel cell runs at $85 \%$ utilization and at a current density of $0.6 \mathrm{~A} / \mathrm{cm}^{2}$. Therefore, the flow of hydrogen through the filter and the fuel cell is $3.7 \mu \mathrm{mol} / \mathrm{cm}^{2}$ s. For a filter operating as demonstrated here (i.e., switching time of $20 \mathrm{~s}$ ), the average $\mathrm{CO}$ oxidation rate is $0.00775 \mu \mathrm{mol} / \mathrm{cm}^{2} \mathrm{~s}$ (i.e., $0.155 \mu \mathrm{mol} \mathrm{CO} / \mathrm{cm}^{2}$ divided by $20 \mathrm{~s}$ ). Hydrogen oxidation involves hydrogen atoms adsorbed onto $67 \%$ of the active sites, those not covered by $\mathrm{CO}\left(0.155 \mu \mathrm{mol} \mathrm{H}_{2} / \mathrm{cm}^{2}\right)$, and hydrogen in the gas phase $\left(1.02 \mu \mathrm{mol} \mathrm{H}_{2} / \mathrm{cm}^{2}\right.$ because, for this reformate stream, $10.2 \mu \mathrm{mol} \mathrm{H}_{2}$ occupies the $0.458 \mathrm{~cm}^{3}$ volume of the $10 \mathrm{~cm}^{2}$ cell). Therefore, the average hydrogen oxidation rate is $0.0588 \mu \mathrm{mol} / \mathrm{cm}^{2} \mathrm{~s}$, and the $\mathrm{CO}: \mathrm{H}_{2}$ selectivity is $1: 7.6$ (i.e., $0.000775: 0.0588$ ). This corresponds to a loss of $\sim 1.5 \%$ of hydrogen in the reformate stream. If the reformate stream was a more realistic $0.5 \% \mathrm{CO}(5000 \mathrm{ppm})$, and the capacity per area of the filter was increased by a reasonable factor of 5 , the loss of hydrogen would still be less than $5 \%$.

\section{Conclusions}

We demonstrated a twin-cell filter design to decrease the $\mathrm{CO}$ concentration in nitrogen from 1000 to $10 \mathrm{ppm}$ in a gas stream flowing at $100 \mathrm{~cm}^{3} / \mathrm{min}$ through $10 \mathrm{~cm}^{2}$ filter cells. It was observed that the performance of the filter is usually determinable from the adsorption breakthrough curve. For example, the exit $\mathrm{CO}$ concentration decreased with a decrease in switching time from 30 to $20 \mathrm{~s}$, consistent with the breakthrough curve. However, a limit is reached such that a small switching time is not sufficient to remove $\mathrm{CO}$ during the oxidation step. Therefore, at a switching time of $10 \mathrm{~s}$, the $\mathrm{CO}$ concentration exiting the filter eventually surpassed that of the $20 \mathrm{~s}$ switching time. The parasitic loss of hydrogen from a corresponding reformate stream was estimated to be $1.5 \%$.

University of South Carolina assisted in meeting the publication costs of this article.

\section{References}

1. J. W. Ha, J. H. Jang, J. H. Gil, and S. H. Kim, Int. J. Hydrogen Energy, 33, 2059 (2008)

2. H. F. Oetjen, V. M. Schmidt, U. Stimming, and F. Trila, J. Electrochem. Soc., 143, 3838 (1996)

3. L. P. L. Carrette, K. A. Friedrich, M. Huber, and U. Stimming, Phys. Chem. Chem. Phys., 3, 320 (2001).

4. J. J. Baschuk and X. Li, Int. J. Energy Res., 25, 695 (2001).

5. S. J. Lee, S. Mukerjee, E. A. Ticianelli, and J. McBreen, Electrochim. Acta, 44 3283 (1999).

6. B. Lakshmanan, W. Huang, D. Olmeijer, and J. W. Weidner, Electrochem. SolidState Lett., 6, A282 (2003).

7. Y. Song, J. M. Fenton, H. R. Kunz, L. J. Bonville, and M. V. Williams, J. Electrochem. Soc., 152, A539 (2005).

8. S. Gottesfeld and J. Pafford, J. Electrochem. Soc., 135, 2651 (1988)

9. P. S. Fedkiw, C. L. Traynelis, and S.-R. Wang, J. Electrochem. Soc., 135, 2459 (1988).

10. E. H. Majlan, W. R. W. Daud, S. E. Iyuke, A. B. Mohamad, A. A. H. Kadhum, A. W. Mohammad, M. S. Takriff, and N. Bahaman, Int. J. Hydrogen Energy, 34, 2771 (2009)

11. S. H. Oh and R. M. Sinkevitch, J. Catal., 142, 254 (1993).

12. C. D. Dudfield, R. Chen, and P. L. Adcock, Int. J. Hydrogen Energy, 26, 763 (2001).

13. M. Echigo and T. Tabata, Appl. Catal., A, 251, 157 (2003).

14. A. Manasilp and E. Gulari, Appl. Catal., B, 37, 17 (2002).

15. S. Kasaoka, E. Sasaoka, Y. Okazaki, and M. Hanaya, Kagaku Kogaku Ronbunshu, 17, 732 (1991).

16. M. A. Vannice, J. Catal., 37, 462 (1975).

17. J. L. Bousquet and S. J. Teichner, Bull. Soc. Chim. Fr., 10, 3687 (1972).

18. M. Echigo and T. Tabata, J. Chem. Eng. Jpn., 37, 75 (2004).

19. B. Lakshmanan, W. Huang, and J. W. Weidner, Electrochem. Solid-State Lett., 5, A267 (2002).

20. H. A. Gasteiger, N. Markovic, P. N. Ross, and E. J. Cairns, J. Phys. Chem., 98, 617 (1994).

21. T. Vidakovic, M. Christov, and K. Sundmacher, Electrochim. Acta, 52, 5606 (2007).

22. V. A. Sethuraman, B. Lakshmanan, and J. W. Weidner, Electrochim. Acta, 54, 5492 (2009).

23. W. Vogel, L. Lundquist, P. Ross, and P. Stonehart, Electrochim. Acta, 20, 79 (1975). 